\title{
Development of Pay Television Channels in China
}

\author{
Fanbin Zeng ${ }^{1} \&$ Wu Heng ${ }^{1}$ \\ ${ }^{1}$ College of Journalism and Communication, Jinan University, Guangzhou, China \\ Correspondence: College of Journalism and Communication, Jinan University, No. 601, Huangpu Dadao West, \\ Tianhe District, Guangzhou 510632, China. Tel: 86-137-6078-7115. E-mail: zengfanbin@vip.sina.com; \\ violet9108@163.com
}

\author{
Received: September 2, 2012 Accepted: September 18, 2012 Online Published: September 28, 2012 \\ doi:10.5539/ach.v5n1p34 \\ URL: http://dx.doi.org/10.5539/ach.v5n1p34
}

This Project was financed by 2012 General Foundation of the Twelfth Five-Year Plan of Guangzhou Philosophy and Social Science Research (Grant Number: 2012YB31; Grant Title: Effect of Time Spent Online and Patterns of internet use on Real-life Political Participation: Based on Empirical Study on Internet Users in Guangzhou).

\begin{abstract}
In 2003, the State Administration of Radio, Film and Television (SARFT) determine those network development years and released a policy document. This indicates that management is aware of the importance of pay TV and digital TV and hoping to promote the development of network services and system integration, and change the business model of the radio and television industry has long rely solely on advertising.

As of July 2009, approved by the State Administration of Radio, Film and Television to set up a pay TV channel has 142 units, divided into two categories broadcast on nationwide broadcast and province. In 7 years, the national digital pay TV channels from scratch, from small to large, from more than 20 of the initial development to the current level of 142 , the number increased by 7 times.

Judging from the number of digital pay channels have begun to take shape, the categories covered very rich. But from the overall development situation of Chinese digital TV, pay-TV channels, the number of users is far less than the (wired) digital TV subscribers, the development is very optimistic. 2010 cable industry revenues constitute the revenue of the premium channels is also very small.

At present, China has a number of pay-TV channels integrated operating agencies, the premium channels transmission operators institutions user access and pay channels, operations, CCTV and local TV stations to form a pay channels.
\end{abstract}

Keywords: development, pay television channels, well-known premium channels, operating agency

\section{Achievements and Problems of Pay Television Channels in China}

In January 2003, the State Administration of Radio Film and Television (SARFT) determined this year to be the Year of the network, and its main tasks are firstly to develop the Pay television, focusing on central and local governments, the establishment of the program operation of the network business, transport, service delivery platform. Then it also develops Internet companies to absorb the forces of society, the development of online audio, video and value-added services and so on. In addition, they strive to make Pay television subscribers in China reach 30 million and network revenue as the main source of economic growth in three years." The introduction of these policy documents means that the management is aware of the importance of Pay television and digital TV, and hopes to promote the development of network services and system integration, change the radio and television industry which has long been relying solely on the advertising business model. However, the Pay television and digital TV has its own unique relationship and their own respective position, namely that Pay television is one of the only digital cable TV applications business. The overall conversion strategy refers to digital television. Among the digital process, the radio and television industry creates Pay television channel, carry out specialized reform and the progressive development of Pay television according to market conditions.

On July 1, 2003, the program called "Rule of Law World", organized by the Shanghai Media \& Entertainment Group, becomes the China's first digital Pay television programs. The program firstly has 20000 terminal users. The "rule of law world" is a file of professional law Programs, which broadcasts 24 hours a day. The premiere of 
the program is from 19:00 to 23:00 at night, while the rest of time is for reruns. Its contents include the dynamic news, the rule of law, documentary, variety shows and so on, such as "Police reports", "Forensic Detective", "Case Focused", "Oriental 110". The development goals set by the Pay television are to establish pay radio and television channels with prominent brand, distinctive features, content-rich, complete range in 3 to 5 years. On September 1, 2003, SARFT approved the first batch of 10 digital pay TV channels, including such program as "Football", "Television Series", "Musical Fashion", "Classical Peking Opera", "City Sports", "Health", and "BTV Theater", "Dynamic Music", "Love Home shopping" of the Beijing Radio, Film and Television Group, "Home Theater" of the Movie Satellite channels program production center is also pilot at the same time. On August 1, 2004, approved by the State Administration of Radio Film and Television, the digital pay channels via satellite transmission, greatly improve the coverage. August 9, CCTV Storm dissemination Co., Ltd. the first batch of six digital Pay television channel took the lead in full the revised into a formal broadcast by the trial broadcast. (Zhou \& Ou, 2008)As of July 2009, approved by the State Administration of Radio, there are 142 set of offering Pay television channels which have been divided into two types of broadcast: the national broadcast and the province. During more than seven years, the national digital Pay television channel develop from scratch, from small to large, from more than 20 in the initial to the current 142, the number increased by 7 times. In volume terms, Chinese digital pay channel has begun to take shape.

Table 1. Pay television directory - as of July 2009

\begin{tabular}{|c|c|c|c|}
\hline Item & Serial number & Start-up units & Program Name \\
\hline \multirow{24}{*}{$\begin{array}{c}\text { Pay-TV } \\
\text { broadcast } \\
\text { nationally }\end{array}$} & 1 & China National Radio & Family Health \\
\hline & 2 & China National Radio & CNR shopping \\
\hline & 3 & CCTV & Health \\
\hline & 4 & CCTV & Fengyun Football \\
\hline & 5 & CCTV & Golf and Tennis \\
\hline & 6 & CCTV & Culture of quality \\
\hline & 7 & CCTV & Fengyun Music \\
\hline & 8 & CCTV & The First Theater \\
\hline & 9 & CCTV & Nostalgic Theater \\
\hline & 10 & CCTV & Fengyun Theater \\
\hline & 11 & CCTV & World Geography \\
\hline & 12 & CCTV & TV Guide \\
\hline & 13 & CCTV & Defense and military \\
\hline & 14 & CCTV & Women Fashion \\
\hline & 15 & CCTV & $\begin{array}{l}\text { CCTV Shopping CO., } \\
\text { LTD }\end{array}$ \\
\hline & 16 & China International Radio & Universal Wonders \\
\hline & 17 & $\begin{array}{l}\text { Program Production Center of } \\
\text { Movie Satellite channel }\end{array}$ & Home Theater \\
\hline & 18 & $\begin{array}{l}\text { Program Production Center of } \\
\text { Movie Satellite channel }\end{array}$ & HD Movies \\
\hline & 19 & $\begin{array}{l}\text { Program Production Center of } \\
\text { Movie Satellite channel }\end{array}$ & Action Movie \\
\hline & 20 & Broadcasting Science Academy & Youth Academy \\
\hline & 21 & $\begin{array}{l}\text { China Central Newsreel and } \\
\text { Documentary Film Studio }\end{array}$ & Stock Information \\
\hline & 22 & $\begin{array}{l}\text { China Central Newsreel and } \\
\text { Documentary Film Studio }\end{array}$ & Old Story \\
\hline & 23 & $\begin{array}{l}\text { China Central Newsreel and } \\
\text { Documentary Film Studio }\end{array}$ & Xinke Animation \\
\hline & 24 & $\begin{array}{c}\text { Beijing Science Education Film } \\
\text { Studio }\end{array}$ & Voyage of discovery \\
\hline Pay-TV & 25 & $\begin{array}{l}\text { Beijing Science Education Film } \\
\text { Studio }\end{array}$ & High school students \\
\hline
\end{tabular}




\begin{tabular}{|c|c|c|c|}
\hline \multirow{20}{*}{$\begin{array}{l}\text { broadcast } \\
\text { nationally }\end{array}$} & 26 & China Education TV & Early Education \\
\hline & 27 & $\begin{array}{c}\text { China Federation of Logistics \& } \\
\text { Purchasing }\end{array}$ & Oriental Logistics \\
\hline & 28 & $\begin{array}{l}\text { China Meteorological } \\
\text { Administration }\end{array}$ & $\begin{array}{l}\text { Chinese Academy of } \\
\text { Meteorological }\end{array}$ \\
\hline & 29 & $\begin{array}{l}\text { Chinese Culture Exchange and } \\
\text { Promotion Association }\end{array}$ & $\begin{array}{l}\text { Painting and Calligraphy } \\
\text { channel }\end{array}$ \\
\hline & 30 & $\begin{array}{l}\text { Chinese Culture Exchange and } \\
\text { Promotion Association }\end{array}$ & Audio-visual World \\
\hline & 31 & $\begin{array}{c}\text { Disease Control and Prevention } \\
\text { Center }\end{array}$ & Health of the people \\
\hline & 32 & $\begin{array}{c}\text { Beijing Radio, Film and Television } \\
\text { Group }\end{array}$ & Dear Baby \\
\hline & 33 & $\begin{array}{c}\text { Beijing Radio, Film and Television } \\
\text { Group }\end{array}$ & Fans channel \\
\hline & 34 & $\begin{array}{c}\text { Beijing Radio, Film and Television } \\
\text { Group }\end{array}$ & Exam online \\
\hline & 35 & $\begin{array}{c}\text { Beijing Radio, Film and Television } \\
\text { Group }\end{array}$ & Fishing channel \\
\hline & 36 & $\begin{array}{c}\text { Beijing Radio, Film and Television } \\
\text { Group }\end{array}$ & Global Travel \\
\hline & 37 & $\begin{array}{c}\text { Beijing Radio, Film and Television } \\
\text { Group }\end{array}$ & New Entertainment \\
\hline & 38 & Shanghai TV & East Day Finance \\
\hline & 39 & Shanghai TV & Animation Show \\
\hline & 40 & Shanghai TV & Game Fengyun \\
\hline & 41 & Shanghai TV & Documentary \\
\hline & 42 & Shanghai TV & Colorful Drama \\
\hline & 43 & Shanghai TV & Rule of Law World \\
\hline & 44 & Shanghai TV & The Charm of Music \\
\hline & 45 & Shanghai TV & Madden Sports channel \\
\hline \multirow{16}{*}{$\begin{array}{c}\text { Pay-TV } \\
\text { broadcast } \\
\text { nationally }\end{array}$} & 46 & Shanghai TV & Urban theater \\
\hline & 47 & Shanghai TV & Laughter Theater \\
\hline & 48 & Shanghai TV & Fast car \\
\hline & 49 & Shanghai TV & Happy lottery \\
\hline & 50 & Shanghai TV & Golden channel \\
\hline & 51 & Shanghai TV & Lifestyle \\
\hline & 52 & Shanghai TV & New Vision \\
\hline & 53 & Tianjin TV & Era home \\
\hline & 54 & Tianjin TV & Era of food \\
\hline & 55 & Tianjin TV & Era of travel \\
\hline & 56 & Tianjin TV & Era of fashion \\
\hline & 57 & Shanxi TV & Lottery online \\
\hline & 58 & Shanxi TV & $\begin{array}{l}\text { The Happiness of Old } \\
\text { People channel }\end{array}$ \\
\hline & 59 & Shanxi TV & Excellent Shopping \\
\hline & 60 & Zhejiang TV & $\begin{array}{l}\text { The World of Study } \\
\text { Abroad }\end{array}$ \\
\hline & 61 & $\begin{array}{l}\text { Zhejiang Radio and Television } \\
\text { Group }\end{array}$ & The Digital Era \\
\hline
\end{tabular}




\begin{tabular}{|c|c|c|c|}
\hline \multirow{46}{*}{$\begin{array}{c}\text { Pay-TV } \\
\text { broadcast } \\
\text { nationally }\end{array}$} & 62 & Guizhou TV & Tianyuan Go \\
\hline & 63 & Guizhou TV & Photography \\
\hline & 64 & Guizhou TV & Home Shopping \\
\hline & 65 & Hunan TV & Happy Shopping \\
\hline & 66 & Hunan TV & $\begin{array}{l}\text { Primary and Secondary } \\
\text { Synchronization Counsel }\end{array}$ \\
\hline & 67 & Hunan TV & Vanguard Records \\
\hline & 68 & Hunan TV & $\begin{array}{l}\text { Table Tennis and } \\
\text { Badminton channel }\end{array}$ \\
\hline & 69 & Jiangsu TV & Dressed up channel \\
\hline & 70 & Jiangsu TV & Wealth of the world \\
\hline & 71 & Jiangsu TV & English learning \\
\hline & 72 & Jiangsu TV & $\begin{array}{l}\text { Early Childhood } \\
\text { Education }\end{array}$ \\
\hline & 73 & Liaoning TV & Game Sport \\
\hline & 74 & Liaoning TV & E-sports \\
\hline & 75 & Liaoning TV & Network chess \\
\hline & 76 & Liaoning TV & Intellectual interest \\
\hline & 77 & Liaoning TV & New Animation \\
\hline & 78 & Liaoning TV & $\begin{array}{l}\text { Family Wealth } \\
\text { Management }\end{array}$ \\
\hline & 79 & Jilin TV & Basketball \\
\hline & 80 & Southern Media Group & Cruise \\
\hline & 81 & Guangdong TV & The Golf channel \\
\hline & 82 & Guangdong TV & European Football \\
\hline & 83 & Guangdong TV & English tutoring \\
\hline & 84 & Guangdong TV & Happy Pet \\
\hline & 85 & Guangdong TV & Exhibition channel \\
\hline & 86 & Guangdong TV & Happy Puzzle \\
\hline & 87 & Chongqing TV & Auto channel \\
\hline & 88 & Chongqing TV & Acrobatics channel \\
\hline & 89 & Chongqing TV & Fashion shopping \\
\hline & 90 & Shandong TV & Favorite world \\
\hline & 91 & Shandong TV & Reading channel \\
\hline & 92 & Hubei TV & Gave birth to guide \\
\hline & 93 & Hubei TV & The discs City channel \\
\hline & 94 & Hubei TV & Career Guide \\
\hline & 95 & Anhui TV & Family Shopping \\
\hline & 96 & Anhui TV & Figures channels \\
\hline & 97 & Henan TV & Pear channel \\
\hline & 98 & Henan TV & Martial Arts World \\
\hline & 99 & Henan TV & Relics treasure trove \\
\hline & 100 & Shanxi TV & Legal services \\
\hline & 101 & Shanxi TV & Baby Care Collection \\
\hline & 102 & Inner Mongolia TV & Urban Construction \\
\hline & 103 & Inner Mongolia TV & Chess channel \\
\hline & 104 & Inner Mongolia TV & House equipment \\
\hline & 105 & Henan National Radio & Origin of Chinese Characters \\
\hline & 106 & Gansu TV & Housekeeping Channel \\
\hline & 107 & Jiangsu TV & Fashion shopping \\
\hline
\end{tabular}




\begin{tabular}{|c|c|c|c|}
\hline & 108 & Changsha TV & Modern women \\
\hline & 109 & Chengdu TV & Delicious food \\
\hline & 110 & Taiyuan TV & Toy Puzzle \\
\hline & 111 & Qingdao TV & Chinese cuisine \\
\hline & 112 & Shenzhen TV & DV life \\
\hline \multirow{10}{*}{$\begin{array}{l}\text { Pay-TV } \\
\text { broadcast in } \\
\text { province }\end{array}$} & 1 & $\begin{array}{l}\text { Beijing Radio, Film and Television } \\
\text { Group }\end{array}$ & BTV Theater \\
\hline & 2 & $\begin{array}{c}\text { Beijing Radio, Film and Television } \\
\text { Group }\end{array}$ & Happy Home shopping \\
\hline & 3 & $\begin{array}{c}\text { Beijing Radio, Film and Television } \\
\text { Group }\end{array}$ & Dynamic music \\
\hline & 4 & $\begin{array}{c}\text { Beijing Radio, Film and Television } \\
\text { Group }\end{array}$ & Chess playing \\
\hline & 5 & $\begin{array}{c}\text { Beijing Radio, Film and Television } \\
\text { Group }\end{array}$ & Real Estate Channel \\
\hline & 6 & Jilin TV & Northeast opera \\
\hline & 7 & Heilongjiang TV & Longjiang Exam \\
\hline & 8 & Shandong TV & Qilu theater \\
\hline & 9 & Shandong TV & House equipment \\
\hline & 10 & Shandong TV & Happy Childhood \\
\hline \multirow{20}{*}{$\begin{array}{l}\text { Pay-TV } \\
\text { broadcast in } \\
\text { province }\end{array}$} & 11 & Chongqing TV & New Economy \\
\hline & 12 & Chongqing TV & Glamor fashion \\
\hline & 13 & Southern Media Corporation & Happy shopping \\
\hline & 14 & Guangdong TV & Lingnan opera \\
\hline & 15 & Guangdong TV & Estate \\
\hline & 16 & $\begin{array}{c}\text { Ningbo Broadcast Television } \\
\text { Group }\end{array}$ & Education Online \\
\hline & 17 & Taiyuan TV & Household consumption \\
\hline & 18 & Chengdu TV & Daily TV shopping \\
\hline & 19 & Fujian Education TV & $\begin{array}{l}\text { Family Education } \\
\text { Channel }\end{array}$ \\
\hline & 20 & Jiangsu Education TV & Jiangsu recruit \\
\hline & 21 & Wuhan TV & Consumer Guide \\
\hline & 22 & Xinjiang TV & Entertainment Bazaar \\
\hline & 23 & Xinjiang TV & Tianshan theater \\
\hline & 24 & Xinjiang TV & Education Online \\
\hline & 25 & Shenzhen TV & Yihe shopping \\
\hline & 26 & Changsha TV & Modern Real Estate \\
\hline & 27 & Changsha TV & Household consumption \\
\hline & 28 & Harbin TV & Swan Shopping \\
\hline & 29 & Zhejiang TV & $\begin{array}{l}\text { Good and Convenient } \\
\text { Shopping }\end{array}$ \\
\hline & 30 & Xiamen TV & Heart shopping \\
\hline
\end{tabular}

From the start-up of premium channels, the 112 digital Pay television channel broadcast nationally run by the 39 units. Start-up units are the central-level media (such as CCTV), the central body (such as the China Meteorological Administration, the Chinese nation Culture Association, etc.), the provincial media (such as the provincial television station), and municipal media (such as cities and television). 30 digital pay channels broadcasting province is sponsored by 19 units, including the main provinces, municipal radio and television organizations. Among 142 digital Pay television channels, there are 111 sets by provinces, municipalities and broadcasting organizations. And on the 31 provincial administrative regions except Hong Kong, Macao and Taiwan, there are 24 provinces start up the Pay television channels. It can be seen that provincial and municipal 
television stations has been the main force in the digital pay channels.

Paid types of TV channels in China is very rich, almost covering the various categories of culture, education, sports, life, entertainment, including a documentary class, games, sports, film, lifestyle, finance and economics, heritage classes, children's classes science class, lottery class, heritage and so on. It can be seen that, to the audience segmentation, digital pay channels have more massed channels, such as Madden sports channel and theater; also appear in a lot of niche specialty channels, such as Fishing channel and golf. Film and television channels, sports channels, educational channels, and shopping channels seize the highest proportion on these types of channels.

Some Pay television channels began to be recognized by the users. On March 2010, "the pay channel market monitoring of the 2009 annual report" is issued by the digital broadcasting industry development center in Beijing. The report do a full show on industry information, marketing, floor broadcast, the order of the user market, customer complaints and unsubscribe of pay channels. At the same time, it selects the "CHC home theater" and other fifteen channels as the most of the network to be the popular pay channel, "Chinese cuisine" and other three channels as the most market potential for premium channels, "Chinese Academy of Meteorological" and other five as the most networks concerned by premium channels.

However, from the overall development situation of Chinese digital TV, the percentage of Pay television channel users are only 10 of that of (wired) digital television, the development is far from optimistic. The composition of the national cable industry revenue in 2010, the basic viewing and maintenance costs accounted for $67.10 \%$, broadband access accounted for 5.42 percent of pay channels revenues only accounted for $3.57 \%$ (Xiong \& Lin, 2011). Its concrete manifestation of the following:

First of all, in the prefecture-level city, digital cable TV premium channels opened in higher rate, but the patency rate of county-level cities in the Southwest, Northwest Territories and the provinces digital cable TV premium channels is relatively low.

Second, test results of operations and the number of users from the domestic cable digital pay TV statistics, the average sales price across the country is about 36 yuan/month every household, generally there is the development of digital pay TV subscribers in 20000 households hovering in the so-called "bottleneck" phenomenon, namely, the existence of the program content and the sales price of the two major "bottleneck" effect common restricts the development of wired digital pay TV business, digital pay TV business is difficult to cross 20000 "bottleneck" and enter a stage of rapid development.

Again, from a business point of view, many digital pay channels in recent years have been in a state of "burn". The situation also can be said that the poor operating conditions, has not yet formed a virtuous cycle of funding, and also in the state to make ends meet. More than 140 digital pay TV channels create the annual value of just over one billion, in fact, only a few million dollars of the average of each pay channel can income. As a digital channel content providers (referred to as channel operators), millions of dollars a year of modest subscription revenues may also be insufficient to cover the program purchases production costs (program copyright, etc.).

Therefore, the State Administration of Radio Film and Television has slowed the process of the bid and launch of digital Pay television channels, the fourth trend of Chinese media forum held in Beijing, State Administration of Radio Film and Television Management Division of media organizations Tao Shiming at the meeting that the future may be the number of compression channels, reducing from 132 channels to 20-30 quality programs.

In addition, with the Pay television broadcasting, the relevant policy regulations also introduced. On December 1, 2003, the State Administration of Radio Film and Television issued "a Radio and Television Cable Digital Pay Channel Business Management Interim Measures (Trial)" (GF Office of the word [2003] 1190), the file has clear regulations on the start-up and operation of pay channels, program requirements, services and supervision. On June 7, 2004, the State Administration of Radio Film and Television has released "views on the promotion of digital cable radio and television pay channel operator industrialization (GF community word [2004] No. 569), also on the specific operational problems of the pay channels do the relevant provisions.

\section{Pay-TV Channels in China Production Organizations}

Production organizations Pay television channels refers to a start-up of the pay channels, that is, product manufacturers, suppliers, and can be referred to as channel operators, program providers, content providers. Pay channel production is usually produced by the central and local television stations or primary production team. The top Pay television channels making institutions as the industrial chain of premium channels, the importance of natural self-evident. The table below is for part of the production organizations in China and its production of premium channels. 
Table 2. Part of the production organizations in China and its production of premium channels

\begin{tabular}{ccc}
\hline $\begin{array}{c}\text { Serial } \\
\text { number }\end{array}$ & Production organizations & Premium channels \\
\hline 1 & CCTV Fengyun & World geography, Theater, Fengyun Theater, Fengyun \\
Music, Urbaa Sports, Football Situation
\end{tabular}

\section{Our Pay TV Channels Integrated Operating Agencies}

In China, foreign investment still doesn't enter the frequency, channels, and the transmission network operator. The document focusing on regulating foreign access policy is the introduction of foreign capital on the field of culture. This document prohibits foreign investment in the establishment and operation news agencies, radio stations (stations), television (stations), radio and television transmission coverage networks, radio and television programs produced and broadcast companies, film production companies, internet culture business institutions and Internet service establishments (except Hong Kong and Macao), performing arts groups, film import and distribution and video projection company. The ban on foreign investment engaged in the publication of books and periodicals, master issuing and importing business, audio-visual products and electronic publications, publishing, production, master issuing and import business, and the use of the information network of audio-visual program services, news sites and Internet publishing and other services. The foreign investors shall not be distributed through publications, printing, advertising, cultural facilities and transformation of business activities, in disguise to enter the channel, frequency, layout, editing and publishing publicity business (Xinhua Net, 2005). To this end, the integrated operating agencies to Pay television channels in China are mainly from the capital.

In October 2003, the central digital TV Media Co. Ltd. China DTV Media Inc. Ltd. (referred to as "the number of media") was established. Set up and invested by CCTV, it is the first authorized by the State Administration of Radio Film and Television (SARFT) to pay the Pay television operator platform is the first nationwide coverage, the operation of institutions engaged in the integration and sales agent of the digital Pay television business. In 2004, SARFT issued "Views on the promotion of digital cable radio and television pay channel operator industrialization" and "Notice on the bid to host the national radio and television digital cable premium channels integrated operating agencies". The document set that the China Film Group Corporation, China Radio, Film and Television Network transmission limited liability company, provincial radio and television broadcasters, Radio, Film and Television Group (The total units) can apply to run a national pay channels integrated operating agencies alone or in combination.

In August 2004, the State Administration of Radio Film and Television approved that the Shanghai Media Group, China Film Group Corporation, Guangdong Television Networks, Inc of China. (now renamed the Chinese Cable) and the consortium which is composed by the BAMC digital TV, the Central People's Broadcasting Station, Tianjin TV, Shandong Province Radio and Television, Anhui TV establish something for digital Pay television integration and sales agents operating agencies. Since then, the exclusive monopoly of China DTV Media Inc. Ltdis is broken. In August 2004, the Shanghai Media Interactive company authorized by the Shanghai Media Group, responsible for the Shanghai TV national broadcast TV digital cable premium channels integrated operating platform with operators (referred to as the the SiTV platform). As of November 30, 2006, the the SiTV platform has integrated broadcast 21 sets of digital pay channels and its own integrated broadcast 15 channels while other channels are in collaboration with the national radio and television institutions. In August 2004, the 
integrated operating platform of the China Film Group starts, and this platform is responsible for construction and operation of the Movie Channel with the the Huacheng film television digital programming Co. Ltd., to work together to conduct business. The Huacheng Company is a joint venture by the movie satellite channels, program production center and the China Film Group Corporation. In July 19, 2005, Chinese cable was placed under CCTV, but CCTV owns China DTV Media Inc. Ltd, so the cable basic fade integration platform business. In December 8, 2005, the tripod, as the media in Beijing announced the establishment of operational and formal. Since the four integrated operating agencies all appearances, the following one by one to talk about these four integrated operating agencies.

\subsection{China DTV Media Inc. Ltd}

China DTV Media Inc. Ltd. Co. (Referred to as "the number of media"), set up and investment by CCTV, authorized by the State Administration of Radio Film and Television (SARFT) the first digital Pay television operators platform, is the first nationwide coverage in digital Pay television integration and sales agents operating agencies. Central digital TV Media Co. Ltd. was formally established on May 18, 2004, in the same year it officially launched six Pay television channels on August 9, set a marked price (CCTV Fengyun channel package of 58 yuan a month) for the first time in the country, which means beginning the formal charges. The first Pay television channels are: "World Geography" channel, "Storm Music" channel, the first theater channel, the situation theater channel, Fengyun Olympic first channel (later renamed as "Storm football") and Fengyun Olympic second channels (later renamed as the "Golf Tennis" Channel).

To enter the Chinese digital TV industry since 2004, China DTV Media Inc. Ltd always maintained the leading position in the country: the number of integrated channels, cooperation networks and paid subscribers are the first. As of June 30, 2009, operating income of China DTV Media Inc. Ltd increases $71 \%$ over the same period last year, in addition, summary of revenues accounts for $51 \%$ of the annual operating indicators, completion rates increased by $8 \%$ over the same period last year. The number of integrated broadcasts on pay channels increase from 41 sets to 46 at last year, and the channels have covered 208 national cable networks.

In the integrated channels of China DTV Media Inc. Ltd. platform, in addition to CCTV running "The First Theater", "The Storm Theater", "World Geography", "Storm Music", "Retro Classics", "TV Guide", "Storm Riders", "soccer Golf tennis" these 8 channels, there are "Home Theater" of the China Film Group, "Beautiful Makeup" in Jiangsu channel, "game competitive" in Liaoning channel, "Auto" in Chongqing channel, "Tianyuan Go" in Guizhou channel, "the Guide of Pregnancy" in Hubei channel, "the World of Study Abroad" in Zhejiang channel, "Auspicious Shopping" in Jilin channel and so on.

On May 9, 2004, China DTV Media Inc. Ltd. set up the China DTV Production Co., Ltd. (referred to as CCTV Fengyun).The CCTV situation, the pay channels content producer, is set up in order to start-up and operations for digital Pay television channels. Commissioned by CCTV, the China Dtv Production Co., Ltd. is in the charge of China DTV Media Inc. Ltd, while it is responsible for the CCTV to content of pay channels. The China DTV Production Co., Ltd and China DTV Media Inc. Ltd these two companies together form the basis business of the CCTV digital Pay television the new career clusters. CCTV situation carefully establishes the distinctive, high quality digital pay channels, namely the "World Geography", "First Theater", "The Storm Theater", "Storm Music", "Storm football", "Golf Tennis" nostalgia theater, "CCTV Products", "National defense", "Women Fashion" and "CCTV Opera" and "CCTV Entertainment" channels which broadcast in the Great Wall platform of North America. The China Dtv Production Co., Ltd. following set the general manager's office, the Finance Ministry, the Ministry of traffic and Integration Division overseas, drama Integration Division, the entertainment industry, documentaries Integration Division, produced a, produced two strategies and advertising Business Operations Department. From the specific point of view, China DTV Media Inc. Ltd. has the following characteristics.

\subsubsection{A Lot of Original Content}

China DTV Media Inc. Ltd. owns CCTV exclusive rights, relying on CCTV Audio Archive images and video resource reserves, with 300,000 hours of all programs, of which $7000 \mathrm{TV}$ series, 45,000 hours; variety shows 40,000 hours, 40,000 hours of special programs, 30,000 hours sports programs, as well as CCTV per day to 300 hours of new programs and to establish a long-term stable cooperative relations with ITV, BBC and HBO.

\subsubsection{Explore New TV Approach to Reading}

Subscription services, payment options, digital TV consumption are typical of individual consumption, and how to provide convenient, personalized viewing choices for viewers becomes the new exploration missions. China DTV Media Inc. Ltd. (CDM) is exploring a new content organization way to explore the idea of programming in 
line with audience personalization options and the high-end services that meet user needs in order to meet the television reading way "I like, I chose, I pay" that is nurtured by the Chinese audiences.

\subsubsection{Expand the Network of New Media}

In July 2007, China DTV Media Inc. Ltd. produces Video Electronics Monthly Magazine "Communes" (www.commune.net.cn). "Communes" includes graphics, video and audio, whose content includes the wonderful promo for the information of the digital TV industry and China DTV Media Inc. Ltd channels, users can be viewed online or download to watch. "Communes" in the users of China DTV Media Inc. Ltd is a function far more than the traditional paper-based program from electronic program book. At the same time, message boards, forums and other functions increase net friends, users and China DTV Media Inc. Ltd. of communication channels.

On September 18, 2007, the central digital TV Media Co., Ltd. with CCTV International Networks Co., Ltd. (The national cultural system reform advanced businesses in 2009) held the opening ceremony and press releases will on Chinese television network (www.tv.cn) a comprehensive revision of on-line. As an important measure that China DTV Media Inc. Ltd carry out the idea of expanding network of new media, Chinese television networks, "reloaded" opened the prelude in China DTV Media Inc. Ltd to open up the network of new media. Chinese television network is not only to connect the entire digital Pay television industry chain link channels, operators and network service providers to provide the information release platform, but also to understand the concern of users of digital Pay television, the user digital pay TV network window.

\subsubsection{The Founder of the Free to Guides Channels - TV Guide Channel}

As the window for audiences to understand the digital Pay television, the channel broadcasts in digital TV and analog TV at the same time, so digital TV conversion region can watch for free. At present, free take a look through the guides of the channel program content and program content excerpt, the TV Guide Channel covering more than 60 million cable TV subscribers played a significant advocacy role in China DTV Media Inc. Ltd for digital pay-channel marketing.

\subsubsection{Make Use of CCTV Propaganda Media}

As CCTV digital Pay television operating agencies, China DTV Media Inc. Ltd has been strong support for open CCTV advertising resources. DTV Media has produced a large number advertising films of pay channels to put multiple channels of CCTV. These commercials as the core products mainly publicize exciting program content of all the pay channels in order to stimulate the audience for digital Pay television ratings desire, thereby promoting the spread of pay channels awareness in China DTV Media Inc. Ltd.

\subsubsection{Establish and Improve the Feedback Channel}

China DTV Media Inc. Ltd hotline (010-51925192) had been opened in the early stage of development of business. It also cooperated with CCTV, making use of the answering agent $7 * 24$ hours service. Through the customer service calls in a timely manner to answer user questions, and help users to solve problems encountered in the actual watch, record user feedback. Analyzing phone customer feedback is to improve the channels of programming and marketing strategies. Customer service phone make pay channel users truly experience human service of China DTV Media Inc. Ltd., improving the user's sense of belonging and loyalty.

\subsection{Topv Media}

Topv digital TV media Co., Ltd. (referred to as the Topv) is the Film and Television nationwide digital Pay television integration operator, approved by the State Administration of Radio. It is jointly founded by Beijing BAMC Digital Television Limited, the Central People's Broadcasting Station, Tianjin era Tianchuang Media Development Co., Ltd., Shandong Province Radio and Television, Anhui TV five shareholders.

Topv digital TV media Co., Ltd. operate the integration, transmission and marketing business of a national digital Pay television. The company is committed to expand the national digital Pay television market and promote the development of the digital TV industry, providing premium channels, video on demand and other top video and service for the national digital television viewers. Since 2006 the company provides digital television programs for digital TV-to-home. The Integrated transmission has 33 sets of digital standard-definition programs and five sets of high-definition TV programs. Topv operates national digital television integrated transmission, marketing and distribution business. The premium channels which the company launched have "Dingshiduo" program package, "Dingshi Jiahe" program package, tripod, as the fashion program package, "Ding, as the radio channel" and "Ding, as optional packages" contains the "Si Fishing", "Collection World", "Securities Information", "Family Health", "Era of Furniture", "Era of Food”, "Era of Travel”, "Era of Fashion", 
"Mission City", "Career Guide", "Family Wealth Management", "Car Fans", "Reading", "Entertainment", "Global Travel" and "People", "Testing Online", "Happy pet", "Excellent baby", "Wealth of the World", "Homemaking", "E-Sports", "Digital Age", "Weather", "Health of the People" these 25 digital pay channels.

As the country's largest digital television shopping channel integration, service providers, Topv company also provide integrated transmission and distribution services for "Happy Shopping", "CNR Shopping", "Excellent Shopping", "Fashion Shopping", "Home Shopping", "Every Shopping", "Global Shopping" these 8 digital TV shopping channels. In September 2009, Topv company provide integrated transmission and encryption services for five high-definition TV in Beijing, Hunan, Guangzhou, Shenzhen, Heilongjiang by the inspection and acceptance of State Administration of Radio, Film and Television. Specified in the State Administration of Radio Film and Television HD TV is one of the remote encryption service units in 2010. The Topv digital TV media Co., Ltd. has extensive cooperation with the local cable network operators in the country. As of September 2010, the product of the Topv Company has been in the 159 landing program covering sixty million digital TV subscribers.

\subsection{Huacheng Film}

The Huacheng film and TV television program Co., Ltd. is approved by the State Administration of Radio Film and Television, which is also a joint venture set up by the Movie Channel and the China Film Group Corporation, the company was formally established on March 8, 2004 and put into operation. The Huacheng film and TV television program Co., Ltd. registered capital of 50 million yuan, and its affiliated companies are Beijing Huacheng advertising Co., Ltd. and Beijing Huacheng media Co., Ltd..

The Huacheng positioning the company for digital Pay television channels marketing agents and program integrator is committed to the digital promotion and operation of Pay television in the country. Commissioned by the Movie Channel, Huacheng exclusively and solely agents $\mathrm{CHC}$ series digital premium movie channels (the "CHC home theater" channel, the $\mathrm{CHC}$ action movies channel and the "CHC HD movie" channel) and agents integration, transmission and marketing of other digital Pay television channels. In addition, the company's business involving Video on Demand (VOD), the site on demand, China Mobile Multimedia Broadcasting service (CMMB), and import and export agents, etc., the future business will be involved in the Near Video on Demand (NVOD), network TV, IP TV and mobile video (3G mobile phones) and the extension of the field of digital TV and related value-added services. At present, the cooperation of the provinces and cities Networks which sign with the Huacheng companies has reached 137 units, the $\mathrm{CHC}$ home theater channel has covered 31 provinces and regions across the country of about 50 million digital TV subscribers; the CHC action movie channel has covered 31 provinces and regions of about 45 million digital TV subscribers.

In the beginning of its establishment, The Huacheng company's main business is to promote marketing of the "CHC home theater" channel run by the China Movie Channel, and can agent other digital pay channel marketing in the country. In September, 2003, it approved by the State Administration of Radio Film and Television, Chinese first digital premium movie channels "CHC home theater" officially launched. It's runned by the China Movie Channel, the Huacheng film and TV television program Co., Ltd., broadcasting nationwide. The main content of "CHC home theater" channel is Chinese and foreign feature films, bringing together the vast majority of domestic films, the wonderful movies of the world, exclusive production of the movie channels and high definition digital movies. In 2009, in order to better meet the needs and aspirations of the majority of the audience, the characteristics Studios movie schedule re-revision. "CHC home theater" channel owns the service concept "the best of theater, seating up to the theater, the largest space theater, the lowest fares theater", to provide personalization options for the majority of TV viewers a new model to enjoy movies and create a movie new life. Order rate survey data from the Pay television shows that "home theater" and "action theater" of the $\mathrm{CHC}$ has been into the national sales of the top three for two consecutive years.

\subsection{SiTV}

Established in December 2001, Shanghai Media interactive TV Co., Ltd. which was invested by Chinese second largest media agencies, Shanghai Media Group, is the digital Pay television content broadcast institutions in Shanghai, also Chinese largest digital pay channel integrated operating agencies, one of digital TV channels and multimedia content body providers and service providers. In August 2003, the Shanghai Media interactive TV Co., Ltd. passed the ISO 9001 quality management system certification.

Since, the first pilot of the national launch of digital TV operators in September 28, 2002, the integrated operating platform construction of the the SiTV national digital pay channels has begun to take shape. The SiTV has launched 30 pay TV channels and the theme TV programs. Its annual integrated program broadcast time adds up to 60,000 hours and the scale is in the leading position in the country. As of June 2005, Shanghai Media 
interactive TV approved laughter theater, city theater, Madden sports channel, the colorful drama, gold, the charm of music, the world of the rule of law, health, speed car, documentaries, games, News and cartoon show these 17 paid radio and television channel frequency, and its program signal has covered the 45 million users in 25 provinces and municipalities, ranking the leading position in the country.

Shanghai Media interactive TV Co., Ltd. (SiTV) was established in December 31, 2001, the operating entity of Radio and Television Shanghai to digital TV and video on demand service the Shanghai Radio and Television's (formerly the Shanghai Media Group changed its name to the Shanghai Radio and Television) business entity engaged in digital TV and video on demand service ,is Chinese largest digital cable premium channels integrated operating platform, operators of digital TV channels and multimedia content body providers and service providers. In August 2003, SiTV had passed the ISO9001 quality management system certification. SiTV, located in the multi-channel cross-platform integrated operators of digital interactive content, is the operating entity of the Eastern Media Group's digital TV and video on demand service. As of April 2009, Sitv has 23 million users of digital viewing, covering 220 cities and regions across the country.

With the development of Next Generation Broadcasting (NGB), SiTV works together to create strategic cooperation with Shanghai and Jiangsu NGB as an opportunity to seek a breakthrough in content, platforms, networks. SiTV had signed NGB strategic cooperation agreement with 20 cable network companies on July 31 , 2009, quickly accessed to the cable television market and established NGB platform in Pudong Area at the same time, actively seeking financing. It involved in the whole net income profit-sharing and private network and interactive two-way transformation by investing in the cable network company shares or investment increment.

In the strategic development, SiTV will strive to forging its core competencies: from content providers to the service operators; outside help on the extraordinary development in technology, marketing, capital and so on; increase investment, flexible investment and strive to achieve the company listed. SiTV will strive to be the best National wide grid resource integrator at the NGB times.

The State Administration of Radio Film and Television In the development of digital pay TV, there are clear requirements that all transmission needs of premium channels must be integrated and transmitted on the platform authorized by the State Administration of Radio Film and Television. Therefore, operators of the four Pay television channel authorized by the Administration are taking the framework of the integrated operation and management of the "vertical integration" premium channels, namely upstream to undertake a pay channel operators, downstream docking around the network operators and users, while itself, in the entire Pay television industry chain, plays the role of a number of pay channels, integration and marketing agent. Among four integrated operators, China DTV Media Inc. Ltd currently regards Pay television as the main profitability of digital TV, SMG targets interactive services as the main objective for future development, developing interactive TV content, TopV plans to realize value-added utility for digital pay channels by a small minority channel diversification, the Huacheng Film explores channel integration and network television operation.

\section{Chinese Pay Channel Transmission Operating Agencies}

The pay channel transmission operating agencies refers to agencies making use of national or provincial Cable Radio and Television backbone network establishments to engage in the business of signal transmission of pay channels. Internationally, the main transmission channels, including Pay television cable box direct broadcast satellite, while Pay television in China mainly develops wired digital transmission. Digital transformation makes the network bandwidth increase considerably, the number of network transmission channel increases from a few dozen to 500 units, providing the possibility for the development of a large number of digital pay channel programs.

Network is the foundation of the industry value chain. If there is no network, the entire industry value chains are unable to connect and run. The pay channel transmission operating agencies is responsible for the production of content providers by channel integrators integrated content delivery to users. Networks in this part include the trunk network (Sub-national trunk network, provincial backbone network and the City and County Extension network) and the access network (Subdivision municipal access network and access network at the county level). The access network is directly related to the number of users, amount of access is proportional to the profits of the entire industry. At present, in general, digital pay channels transfer on satellite. That is, channel integrators transfer pay channels to the network around the engine room front-end via satellite, then local Internet service providers will transfer pay channels into the user's home through a local digital cable television network.

However, the traditional pattern of the network transmission industry and the organizational manner of network transmission organizations in China remain a constraint on the development of the premium channels. Due to the "Four television" historical policy, Chinese distributed cable network cannot scale market for Pay television, and 
the high landing fees for Pay television operators cannot be afford. Same time, because there is no uniform national network transmission systems, network service levels to master the most valuable user resources is also difficult to improve. As early as September 17, 1999, the State Council General Office had forwarded the document "Opinions on strengthening the construction management of the radio and television cable network" (Guo, 1999) which was launched by Ministry of Information Industry and State Administration of Radio Film and Television. The document is divided into five parts: First, resolutely put an end to repetitive construction; Second, ensure the secure transmission of radio and television programs; Third, accelerate the pace of reform of the broadcast television industry; Fourth, a significant reduction in network rental; Fifth, continue to comply with the division between the telecommunications sector and broadcasting and television sector. But the integration of the transport mechanism is not very optimistic, scale and potential of Pay television is not fully developed.

\section{Premium Channels User Access to Operating Agency}

Premium channels user access to operating agency refers to the agency making use of radio and television distribution network to provide users with access to the service agencies of the premium channels. Premium channels user access to operating agency, also referred to as network operators, operation and service providers, network providers, etc., is directly responsible for selling to the end-users and customers, specifically referring to is all over the cable networks which are digital pay channels, distributors, and vendors. Premium channels user accessed to operating agency has great control on opening up the pay-channel operations, the establishment of the marketing model, service model, and generate premium channels business value, and drive the upstream and downstream to create and produce value. Pay channels the user access to operating agencies should introduce market competition and incentives to improve the marketing capabilities of premium channels, and enhance efforts to promote the completion of the pay channels of sales and service.

\section{The Well-Known Premium Channels}

\subsection{The "Defense and Military" Channel}

The "Defense and Military" channel of the CCTV Fengyun situation is Chinese first self-made premium channels, and it launched on May 8, 2006. In fact, it is only for defense and military enthusiasts, mainly to disseminate knowledge of national defense service professional channels. The contents of "Defense and Military" channel are both military hot spot analysis, another defense practical review; both well-known Chinese and foreign soldiers style, there are secret of classic examples; technological diffusion of existing equipment, but also the popularization of knowledge of national defense; both a true record of war, there are shadow drama background parsing. Authoritative experts interact online and hardcore military fans actively participate in the channel. "Defense and Military" channel around the various fields of defense and military sets up a variety of different patterns of television programs for different levels of enthusiasts. "Defense and Military" channel sets professional, authority, knowledge, interaction, visual as a whole. There are some main sections, such as "War mystery in the mystery": a secret documentary; "Equipment and Space": the feature film of the comprehensive and systematic display of weapons and equipment knowledge; "Let's Talk": a chat room type of program, users synchronized interactive, passion participation of military fans; "Experts Online": a chat room type of program, users synchronized interaction, expert online doubts; "Full Record of Military": domestic and foreign elite military themes documentary to attract the eye of; "Background on Film and Television": analysis of history, reviews dramas of excellent military theme at home and abroad; "boutique typical broadcast": unique class part of the military magazine.

The "Defense and Military" channel is in a home-made Program, and two-thirds of the Programs are product and edited by the channel. Homemade amount of this program not only in the CCTV situation but in all the pay channels is second to none. Originally, the "Defense and Military" channel is a special and sensitive resources of the television program, advantage of the channel is its monopoly on these resources to a certain extent. First of all, depending on the advantage of proximity to the CCTV, it can fully tap the CCTV resources of the existing military programs, including many valuable historical pictures, equipment information. Rich library of material is an important foundation for the program self-made. Second, the "Defense and Military" channel wins the support of major domestic military sectors, such as the Air Force, Navy, the Second Artillery Corps and more than 30 audio and video units, these units carry out a co-production. The program not only has the authority, more abundant information material, and also avoids other problems caused by sensitive subject matter. Third, the channel, which involves a group of senior military experts to form a powerful group of experts including the country's most influential editor in chief of the major military professional journals, as well as top experts from the authority of the military research institutes such as the National Defense University and the Academy of 
Military Sciences. In addition, there are many professional level military fans participating in, together constituting the authority guest team of the "Defense and Military" channel.

In the daily operations, the "Defense and Military" channel depends not only on saving daily expenses to reduce costs, but also by studying the arrangement of the law, producing programs in the industrial production model, in order to improve efficiency. In aspect of operation and promotion, the channel widely joints various types of military media and power resources, and actively builds China`s heavy weight military media carrier.

\section{2 "Female Fashion" Channel}

CCTV Fengyun situation has created a file of women's fashion channel was formally launched in August 2006.Its characteristics of the channel is gorgeous and beautiful, which has the following characteristics: (1) Their own part unique. The "Female Fashion" channel devoted to establishing their own part to increase the exclusivity of the content of the channel part. It has 2 to 3 own columns such as "Oriental Fashion" and "Style sinks", moreover, it characteristically arranges and centralized propagandas. (2) The channel to promote large-scale activities. "Female Fashion" channel helds costume design activities called "CCTV Innovative Design Winner", which is the integral part of the channel promotion activities. (3) Blog hits ranked first on CCTV. The channel blog plays the leading role of the female fashion, adhering to the creative ideas of original main integration supplemented by exclusive distribution channel the latest information, leading the women's fashion channel blog hits to break 10 million marks, dominating the CCTV top.

The positioning of "Female Fashion" channel is high-end, and its main program is "Oriental Latest Fashion", a fashion information class week broadcast program for the "Female Fashion" channel. The program bases on the background of grand sophisticated oriental culture, telling the modern lifestyle change of Chinese characteristic clothing, star private wardrobe, construction design to show the living landscape of rich oriental style.

The "Fashion Featured" and "Fashion Show" are programs of "Female Fashion" channel that makes introduction of excellent programs of the famous fashion channel Fashion TV, containing from Milan, Paris, New York, London and other world fashion's latest international shows, as well as Chanel, Gucci, Versace and other well-known brand new conferences.

There "Style Sink" is the new date multicast program built by "Female Fashion" channel jointly work together with top fashion magazine "VOGUE". The program shares aura wonderful life of foreign international film star, the chief design guru of the top brands, domestic and foreign elite aristocratic with the users. Among the program, "Clothing" is the chapter about the explains of the most popular clothing comment and the international color by well-known international fashion design masters.

"Peak quality" is designed by "Feminine Fashion" channel for high-end elite men to create a file high-grade video program to displays an elite life, and exchange of the elite thought. Its contents are from yachts to private jets, from designer clothes to high-tech Coldplay.

\subsection{Fengyun Music}

The Fengyun Music channels, an all-day broadcast on global fashion music channels offered by CCTV, is the earliest opening of one of the digital pay TV channels launching on August 9, 2004. "Storm Music" television programs are mainly from Europe, America, Japan and South Korea, Hong Kong, Taiwan and mainland China areas, among which the outside pop music with the exclusive copyright occupies an important position. "Storm Music" channel aims to spread the music and lead the fashion.

CCTV - "Storm Music" channel offered by the CCTV broadcast around the clock "Global star site theme music channels". All Channel Stereo broadcast full star site layout, is the exclusive positioning in the "live concert" professional music channels. CCTV - "Storm Music" television programs, a collection of Europe, America, Japan and South Korea, and Chinese popular live music, which has exclusive rights outside the popular live music programs in the channel plays an important proportion. CCTV program of original music is the main content of the channel.

Storm Music has the following characteristics (1) Global sharing of live music; (2) the world view global presence; (3) the global music festival audiovisual gluttonous feast (Sohu net, 2005 July 26).

\subsection{World Geography}

World Geographic Channel is the channel strongly built by CCTV, and combines with the brand and program advantages of National Geographic to enrich the mind, dissemination of true knowledge, highlight interesting as the first thrust. Broadcasting 19 hours a day, the program includes the endless far-reaching perspective of history, science, nature, military, political, cultural, geographical. World Geographic Channel understands history in 
depth, visits the war front, expands a broad perspective of human geography and explores the rules of survival of the animals' world. The world's most excellent explorers, scientists, photographers and war correspondents assemble here to launch the most powerful sensory impact and soul of the challenge to you.

\subsection{CHC Home Theater}

"CHC home theater" channel is Chinese first digital premium movie channels approved by the State Administration of Radio Film and Television, operated by Movie Channel (CCTV-6) and broadcasting across the country via satellite in September 2003. The main content of "CHC home theater" channel is Chinese and foreign feature films, bringing together the vast majority of domestic films, the wonderful movies of the world, exclusive production of the movie channels and high definition digital movies. The channel, with no commercial advertisings, broadcasts 24 hours a day and turns to release 15 films a day. The channel premieres a new movie at 21 o'clock every day. In 2007, "CHC home theater" channel launched three major characteristics studios containing Weekend Selection (21:00 on every Saturday), "Star Cinema" (22:30 on every Friday) and "Films of Golden Medal" (19:30 on the first Sunday monthly).

\subsection{Chinese Cuisine Channel}

Chinese Food Channel, on the basis of a large Chinese food culture television program "Feast", is the national digital TV premium channel approved by the State Administration of Radio Film and Television, formally launched on September 29, 2006. Broadcasting 24 hours a day, the channel brings together the food sector elite master and juice which shows parts of the world food culture. The channel disseminates practical authentic boutique diet constantly and tastes fashion healthy and delicious throughout.

China famous food channel show the world wine tasting, the program has the world's top wine master to open 50 bottles of "natural wine", most of which are valuable. In addition, the program led audiences to visit the earth of Europe to explore the Chateau Castle, telling about the history of wine, winemaking process, wine culture and wine tasting to you.

The program, "The Delicious Food on the Silk Road", consists of three top chefs from China, France, Malaysia, on behalf of the three cooking schools in the world - Chinese meal, French cuisine meal, Arab meal, which lasted a month, around the ancient Silk Road - the Taklimakan Desert, to enjoy, taste and produce a variety of delicious food from the mysterious ancient and thriving on the land out of their different perspective and food culture accumulation. It also combines western scenery with features and delicacy and enjoys the western unique character in world vision, therefore, led by the top chefs, more people can feel the rich heritage and taste delicacy and customs of the ancient Silk Road.

The program, "Chinese Food Lecture - Food Carving", introduces food carving is the plastic arts to beautify banquet, foil dishes, heighten atmosphere and enhance friendship. Food carving can show their artistic vitality and appeal at either a state banquet or a family celebration banquet, so that people get the material enjoyment, but also get to enjoy the arts. The great variety of food carving, drawing the materials from in wide range of both ancient and modern, flowers, birds, fish and insects, landscape architecture, myths and legends. Materials, which have the meaning of good luck or better symbol, can be used in the form of art.

\subsection{Weather Channel}

The Weather Channel, sponsored by the China Meteorological Administration, co-hosted by China Meteorological Administration, China Meteorological Audio, Video Information Group and the Provincial Meteorological Bureau, was formally launched on May 18, 2006. Now it is agent by Topv Media.

Weather Channel (China Weather TV) is an all-weather providing authoritative, practical, specialized TV channels in the breakdown of the various types of meteorological information and other life service information to disaster prevention and mitigation, to serve the public for the purpose of providing meticulous, professional practicality of meteorological information services and scientific propaganda. Learn from the successful experience on the Weather Channel of the United States, Canada, Australia and other developed countries, Chinese Weather Channel will also use of the way of non-program and whole broadcast channels, opening up to ten minutes as the basic unit, rolling all-day high-frequency and broadcasting content at any time to update.

Broadcasting in this way ensures that as long as the audience turn on the TV, they can watch the desired weather forecast in ten minutes. Weather warning forecasting, weather forecasts for cities and other contents which are closely related with people's lives broadcast 144 times every day, changing the current situation audiences must watch the weather forecast in front of the TV, and greatly enhancing the touch-up rate of the TV weather information. It is said that this arrangement of broadcast television is unique in the current Chinese television media, and its presence will fundamentally change the overall appearance of the TV weather. In addition to the 
meteorological information, the channel will be broadcast on high-frequency information related to the environment, transportation, travel and performances to close to life and serve the public. In the case of event of a major severe weather, the channel continuous live cover. The Weather Channel, the digital television specialty channel to assume the functions of national public meteorological services, is the Public Emergency response early warning disaster prevention information release platform.

On April 20, 2007, the Weather Channel entered Zhong Nanhai television system, and produced the decision-making weather program "the Zhong Nanhai Meteorological Report", providing references on meteorological disaster prevention and decision-making process for the central leadership and the relevant agencies of the State Council.

In July at the same year, the Office of the State Council issued "Views on further strengthening of meteorological disasters", clearly pointing out the need to further improve and expand weather channels. The China Meteorological Administration for the development of the channel to provide a solid technology business support, meteorological products and resources to support. More than 100 weather experts directly involve in program production, interpret climate changes for the audience every day and make timely and accurate analysis.

\subsection{Dressed Up Channel}

Dressed up channel is the most abundant content, updating the most timely and professional fashion TV channels in domestic, running for 24 hours a day, broadcasting premiere programs for eight hours every day and encompassing all aspects of fashion, accessories, makeup and other exciting content. Synchronized with the international fashion, the channel is in alliance with the French fashion television, the Italian fashion channel, TV organizations of Japan and Korea fashion. The channel also broadcasts synchronously the latest trend information from Paris, New York, Milan, Tokyo and other major fashion capitals, so that the domestic audiences feel the international the pulse of fashion at the first time.

The channel collects outstanding production teams on three districts of Cross-straits to create the brand program of the most in, report the domestic fashion information, track the domestic fashion hot spot, and advocate the new trend of Fashion TV entertainment. With style of cutting-edge fashion, authoritative and practical, its content target is beauty, body, clothing, etiquette and other popular information and target audience locked 20-50 year-old middle-aged white-collar workers.

Dressed up channel came out on November 1, 2003, broadcasting continuously for 24 hours to spread beautiful. The channel premieres programs for six hours a day, including four main categories of fashion contents. The first largest category of international fashion show, with a daily capacity of not less than two hours, releases the latest fashion information from the four major fashion capitals of Paris, Milan, New York, Tokyo International. The second largest category of domestic fashion show clean sweep of the city's domestic fashion trendy. The third largest category of all kinds of beauty contests broadcast on national and international top model contests, and the contestants gather in the bright starlight. The fourth largest category of authoritative and practical dress guide, and domestic and international top fashion style masters teach the simple and convenient dress skills to the audiences every day. Dressed up channel has the following columns, such as "Overseas pretty makeup fashion", "Popular release" and "Pretty Makeup Star", "Fashion Club" and "Beautiful Class", "Chinese T station style", "Fashion Sector", "Pretty Makeup Colorful field", in addition, "Beautiful Beat" and "Pretty makeup Street" will soon be set up. The channel is currently the most abundant, the update of the most timely fashion TV channel.

Since August, 2004, Dressed up channel is distributed via Asia Satellite 4 transmission co-packaged promotion with CCTV digital pay channel, coverage area to the central city and the eastern coastal cities, its arrival rate ranked first in similar provincial channels of China. Dressed up channel continued moves forward on the road to spread beauty, making use of all-digital technology to make television ratings more efficient and clear.

\subsection{Games Sports Channel}

Games sports channel is a digital TV pay channel approved by the State Administration of Radio, hosted by the Liaoning TV, broadcasting 24 hours a day from November 1, 2003. Games sports channel aims to guide the competitive gaming television appreciation, create new varieties of game television programs, advocate e-sports competition and develop the healthy and fashion game entertainment and cultural market, regard electronic games as carrier, game scenes of athletic competition as the main communication content quiz game results for the auxiliary form through dissemination of the contents of the quiz game results as a secondary form, with the Internet uplink and interactive channels, games, sports players and the vast majority of TV viewers to participate in the live television (or taped).

The main program of the game sport channel: "Game Report" Game Collection "World on terror" "hegemony 
arena", "e of 11", "Happy Arena Zhiyong Chess Road", games, sports channels, strive through its own powerful the advantage of becoming the most authoritative and influential professional e-sports channel platform, the main organizer of the whole country (or the world) within the scope of e-sports event, and create a new TV column, players and the vast majority of TV viewers to participate and interact .

Game sport channel has exclusive TV rights of WEG, ESWC, CPL, WCG, WSVG, WEF, IEF and the world's other top computer and video games in China. It also has exclusive TV rights of domestic official e-sports competitions nationwide e-sports Games, PGL and other events. With new game information, objective industry comments, brilliant picture of the dynamic and exciting showdown of fierce fighting, the GTV game sport channel gives gamers superior audiovisual enjoyment. The channel steadily ranks national third of the "selection of your favorite premium channels" in the Chinese television network.

\subsection{Madden Sports Channel}

The core content of "Madden sport" channel is basketball and football. Sports fans ranged from 15 to 55 years can stand on a five-star front-line stands to understand all-round various kinds of information of the professional sports leagues of China and the world. "Madden sport" is the only television channel of the country that has all sessions live copyright of Super League and the CBA these two top domestic leagues, live coverage of the Super League, CBA League, French League and Scottish Premier League. The channel not only has wonderful coverage before each round and each game and makes professional reviews after the game, but also timely broadcasts highlights of the game and goals fragments for audiences to appreciate. It broadcasts the top events at the first time and provides professional reviews of first-class level. It is particularly worth mentioning that since 2007, "Madden sport" uses Chinese original sounds of ESPN, the world's leading sports media, to broadcast live Premier League, Champions League, Champions League magazine and Premier League highlights, which make many fans cheered and excited. "Madden Sports" is the digital TV channel of Shanghai's five-star sports and the national audiences can watch it.

\subsection{Fishing Channel}

The Fishing Channel is a file of subscription television Programs of TopV digital TV and Media Limited. The Program of Fishing Channel covers all types of fishing competitions at home and abroad reported that the popularity of fishing knowledge and fish culture, fishing and other products, production and sales of fishing the use of technology and research for the majority of fishing enthusiasts. The Program brought together the essence of the Chinese and foreign excellent fishing Programs to fully meet a full range of needs of enthusiasts. The channel is the first professional fishing outdoor recreation channel: to pass domestic and foreign fishing information and event coverage at the first time, contents set guidance, practical, informative and interesting as a whole.

\subsection{Tianyuan Go Channel}

Tianyuan Go Channel, founded on May 1, 2004, is Chinese first chess professional digital Pay television channel. It, unique in the country, relies on the powerful influence of the media in Guizhou TV, integrating media resources of GuiZhou TV, the newspaper of "Go", Guizhou Radio and Television newspaper, Shanghai Sporten website and Guizhou TV website to form Spread the advantages of spread the advantages of forming a strong three-dimensional coverage. In January 2007, among more than 40 digital TV channels in 2006 Digital TV Forum, Tianyuan Go channel win the title of "digital television pioneer channels" by virtue of its comprehensive strength.

Tianyuan Go Channel is the only one professional TV channel to have a large live ability, and its average monthly live up to 12 events, annual live up to 150 events with 8250 minutes.

Since launching, the channel has several successful transnational broadcast. The championship match of the eighth Nikaya Kiriyama cup in 2006 broadcasted live across China and Japan, which is highly praised by the leadership of the Chinese Chess and many chess fans. Tianyuan Go channel broadcasts live the important events of the eleventh Samsung Insurance Cup final all-weather high-capacity from 9:30 am to 17:30 pm, widely praised by the Go community and television industry.

\subsection{The First Theater}

The main program of the first theater is "Charm Theater", which includes all resources of CCTV and selects high quality and high ratings drama to broadcast; "Premiere Theater" owns the CCTV unique resources, firstly broadcasting the domestic film masterpieces; "Popular Theater" continuously play three exciting Hollywood blockbusters at prime time from 8:00 at night, broadcasting in English soundtrack and accompanied by Chinese subtitles. 
The first theater channel is the premium channel setting up by the CCTV movie channel and the TV channel, and its content includes the latest and classic movies and TV dramas. The Anhui Satellite TV channel has the channel with the same name. The first theater is a professional broadcasting channel of CCTV film and dramas, one of the 12 electronic payment channels set by CCTV.

\section{References}

Ministries: a number of opinions on the introduction of foreign investment in cultural field (2005). Retrieved from http://www.jiaodong.net2005-08-05

The Fengyun music channel revision appears on August 9 (2005). Retrieved from http://it.sohu.com/20050726/n240195884.shtml

Xiong, F., \& Lin, Q. J. (2011). Radio and television development status in 2011-Pay television accounts for 10\% of digital TV subscriber. $\quad$ Retrieved from http://tech.ifeng.com/meeting/special/7th-media/content-1/detail_2011_12/08/11197332_0.shtml,2011.12.8

Zhou, J., \& Ou, W. K. (2008). The opportunity of Pay television brought by live broadcast satellite Satellite and Network (Vol. 12, p. 36). 